\title{
Functional and genetic characterization of clinical malignant hyperthermia crises: a multi-centre study
}

Werner Klingler ${ }^{1,2,8^{*}}$, Sebastian Heiderich ${ }^{1,2,3 \dagger}$, Thierry Girard ${ }^{4}$, Elvira Gravino ${ }^{5}$, James JA Heffron ${ }^{6}$, Stephan Johannsen ${ }^{7}$, Karin Jurkat-Rott ${ }^{2,8}$, Henrik Rüffert ${ }^{9}$, Frank Schuster ${ }^{7}$, Marc Snoeck ${ }^{10}$, Vincenzo Sorrentino ${ }^{11}$, Vincenzo Tegazzin ${ }^{12}$ and Frank Lehmann-Horn ${ }^{2,8}$

\begin{abstract}
Background: Malignant hyperthermia $(\mathrm{MH})$ is a rare pharmacogenetic disorder which is characterized by life-threatening metabolic crises during general anesthesia. Classical triggering substances are volatile anesthetics and succinylcholine (SCh). The molecular basis of $\mathrm{MH}$ is excessive release of $\mathrm{Ca}^{2+}$ in skeletal muscle principally by a mutated ryanodine receptor type 1 (RyR1). To identify factors explaining the variable phenotypic presentation and complex pathomechanism, we analyzed proven MH events in terms of clinical course, muscle contracture, genetic factors and pharmocological triggers.
\end{abstract}

Methods: In a multi-centre study including seven European $\mathrm{MH}$ units, patients with a history of a clinical $\mathrm{MH}$ episode confirmed by susceptible (MHS) or equivocal (MHE) in vitro contracture tests (IVCT) were investigated. A test result is considered to be MHE if the muscle specimens develop pathological contractures in response to only one of the two test substances, halothane or caffeine. Crises were evaluated using a clinical grading scale (CGS), results of IVCT and genetic screening. The effects of $\mathrm{SCh}$ and volatile anesthetics on $\mathrm{Ca}^{2+}$ release from sarcoplasmic reticulum (SR) were studied in vitro.

Results: A total of 200 patients met the inclusion criteria. Two MH crises (1\%) were triggered by SCh (1 MHS, 1 MHE), $18 \%$ by volatile anesthetics and $81 \%$ by a combination of both. Patients were $70 \%$ male and $50 \%$ were younger than 12 years old. Overall, CGS was in accord with IVCT results. Crises triggered by enflurane had a significantly higher CGS compared to halothane, isoflurane and sevoflurane. Of the 200 patients, 103 carried RyR1 variants, of which 14 were novel. CGS varied depending on the location of the mutation within the RyR1 gene. In contrast to volatile anesthetics, SCh did not evoke $\mathrm{Ca}^{2+}$ release from isolated rat SR vesicles.

Conclusions: An MH event could depend on patient-related risk factors such as male gender, young age and causative RyR1 mutations as well as on the use of drugs lowering the threshold of myoplasmic $\mathrm{Ca}^{2+}$ release. SCh might act as an accelerant by promoting unspecific $\mathrm{Ca}^{2+}$ influx via the sarcolemma and indirect RyR1 activation. Most MH crises develop in response to the combined administration of SCh and volatile anesthetics.

Keywords: Malignant hyperthermia, Succinylcholine, Suxamethonium, Volatile anesthetics, RyR1 mutations, In vitro contracture test

\footnotetext{
* Correspondence: werner.klingler@uni-ulm.de

${ }^{\dagger}$ Equal contributors

${ }^{1}$ Department of Neuroanesthesiology, Ulm University, Ludwig-Heilmeyer-Str.

2, Günzburg 89312, Germany

${ }^{2}$ Division of Neurophysiology, Ulm University, Albert-Einstein Allee 11, Ulm

89081, Germany

Full list of author information is available at the end of the article
}

C Biomed Central

(C) 2014 Klingler et al.; licensee BioMed Central Ltd. This is an Open Access article distributed under the terms of the Creative Commons Attribution License (http://creativecommons.org/licenses/by/2.0), which permits unrestricted use, distribution, and reproduction in any medium, provided the original work is properly cited. The Creative Commons Public Domain Dedication waiver (http://creativecommons.org/publicdomain/zero/1.0/) applies to the data made available in this article, unless otherwise stated. 


\section{Background}

Malignant hyperthermia (MH) is a rare autosomal dominant pharmacogenetic muscle disorder. The genetic incidence is thought to be between 1:3,000 and 1:8,500 [1]. Predisposed individuals are at risk of developing a severe drug-induced hyper-metabolic state resulting from altered $\mathrm{Ca}^{2+}$ turnover in the skeletal muscle. Volatile anesthetics and succinylcholine $(\mathrm{SCh})$ are the classical triggering agents. The principal clinical symptoms are hypercapnia, acidosis, generalized muscle rigidity, cardiac arrhythmia and high temperature [1]. These clinical symptoms are used within a clinical grading scale (GCS) to predict the probability of whether a clinical event might be an $\mathrm{MH}$ crisis [2].

In skeletal muscle, the primary mode of $\mathrm{Ca}^{2+}$ release is through direct protein-protein interaction between the voltage sensor of the $\mathrm{t}$-tubular membrane, the dihydropyridine -sensitive L-type $\mathrm{Ca}^{2+}$-channel Cav 1.1 (DHPR) and the ryanodine receptor subtype 1 (RyR1), the $\mathrm{Ca}^{2+}$ release channel of the sarcoplasmic reticulum (SR) (Figure 1A). The RyR1 is identified as a key element in the pathophysiology of $\mathrm{MH}$ $[3,4]$. Currently more than 300 different variants of uncertain significance in the gene coding for RyR1 have been detected, however until now only 31 RyR1 mutations have been proven to be causative for $\mathrm{MH}$ according to the criteria of the European Malignant Hyperthermia Group (see www.emhg.org). In very rare cases, a defect in the $\alpha 1$ subunit of the DHPR has been reported [5], yet in up to $40 \%$ of the MHS families no mutations in either of the two genes could be identified [6,7]. The genetic penetrance is not fully understood because acute $\mathrm{MH}$ episodes are more common in males and children [8].

Muscle of individuals with a RyR1 mutation exhibits an increased sensitivity to volatile anesthetics: in vitro, $\mathrm{MH}$ muscle is more sensitive to halothane compared to other volatile anesthetics [9-12], however clinical studies have yielded inconsistent conclusions [13-15]. The MH diagnostic in vitro contracture test (IVCT) measures abnormally strong contractures as a surrogate marker for halothane or caffeine induced $\mathrm{Ca}^{2+}$ release from the SR [16]. MH susceptibility is a clearly autosomal dominant in vitro. The depolarizing muscle relaxant succinylcholine (SCh) pharmacologically activates the nicotinergic acetylcholine receptor (nAChR) which acts as a nonspecific cation channel resulting in a local long-lasting inward current and corresponding depolarization of the cell membrane. Since the nAChR is permeable to $\mathrm{Ca}^{2+}$, in addition to the depolarisation the entry of $\mathrm{Ca}^{2+}$ may indicate the underlying mechanism of action of $\mathrm{SCh}$ in the pathogenesis of $\mathrm{MH}$. Acute crises triggered by SCh may be caused either by a direct influx of extracellular $\mathrm{Ca}^{2+}$ via the $\mathrm{nAChR}$, by transient depolarization of the voltage-gated DHPR or by unspecific $\mathrm{Ca}^{2+}$ influx such as store-operated $\mathrm{Ca}^{2+}$ entry and $\mathrm{Ca}^{2+}$ entry coupled with excitation [17].
In vitro studies could not show that $\mathrm{SCh}$ alone induces pathological contractures in $\mathrm{MH}$ muscle strips although it did enhance the effect of halothane [18] and caffeine [19]. In vivo models are inconsistent with the in vitro findings: Harrison showed that $\mathrm{MH}$ pigs developed an increase in body temperature and muscle rigidity after administration of SCh alone [20] and in a recently developed micro-dialysis pig model, halothane and not SCh induced a hyper-metabolic reaction [21]. Using 284 suspected clinical MH cases, Dexter et al. demonstrated an increased risk of $\mathrm{MH}$ when $\mathrm{SCh}$ is used in combination with volatile anesthetics while $\mathrm{SCh}$ alone was only rarely seen as a trigger [22]. Additionally, pharmacological SCh formulations used to contain the preservative 4-chloro$\mathrm{m}$-cresol (4-CmC) which has been identified as a potent RyR1 agonist [23]. It was subsequently removed from SCh formulations in the 1980s [24].

The pathophysiology and variability of the clinical course of $\mathrm{MH}$ is not fully understood. A genetic approach is compromised due to numerous mutations of unclear causality, epigenetic factors and the involvement of at least two different $\mathrm{Ca}^{2+}$ conducting proteins. Functional testing (e.g. IVCT, $\mathrm{Ca}^{2+}$ release experiments) can only clarify partial aspects of the pathomechanism of $\mathrm{MH}$. The goal of this study is thus to characterize a large cohort of proven clinical MH events by comparing CGS with functional effects on excised muscle bundles (IVCT) and genetic factors. We were also interested in the $\mathrm{MH}$ specific differences in the in vitro and in vivo characteristics of the classical $\mathrm{MH}$ triggers, i.e. SCh and volatile anesthetics, as these drugs act on different pharmacological pathways.

\section{Methods}

\section{Multi-centre evaluation}

Seven European $\mathrm{MH}$ test units participated in this multicentre study: Basel, Switzerland; Nijmegen, Netherlands; Naples, Italy; Leipzig, Germany; Padua, Italy; Ulm, Germany; and Würzburg, Germany. Patients were included if they suffered from a clinical $\mathrm{MH}$ episode confirmed by a positive or an equivocal IVCT. These experimental investigations were part of the routine diagnostic algorithm used in MH susceptibility testing. Written informed consent was obtained from the patients or their legal guardians. Data collected included age, gender, year of crisis, clinical grading scale (CGS), information of the administration of $\mathrm{MH}$ trigger substances and results of the IVCT. All data sets were imported into a multi-centre database.

\section{Clinical grading scale}

The MH episodes of the patients were analyzed by calculating the clinical grading scales (CGS) according to Larach et al. 1994 [2]. In brief, the CGS is a scoring system estimating the likelihood of an $\mathrm{MH}$ event using several indicators: masseter spasms or generalized muscle 


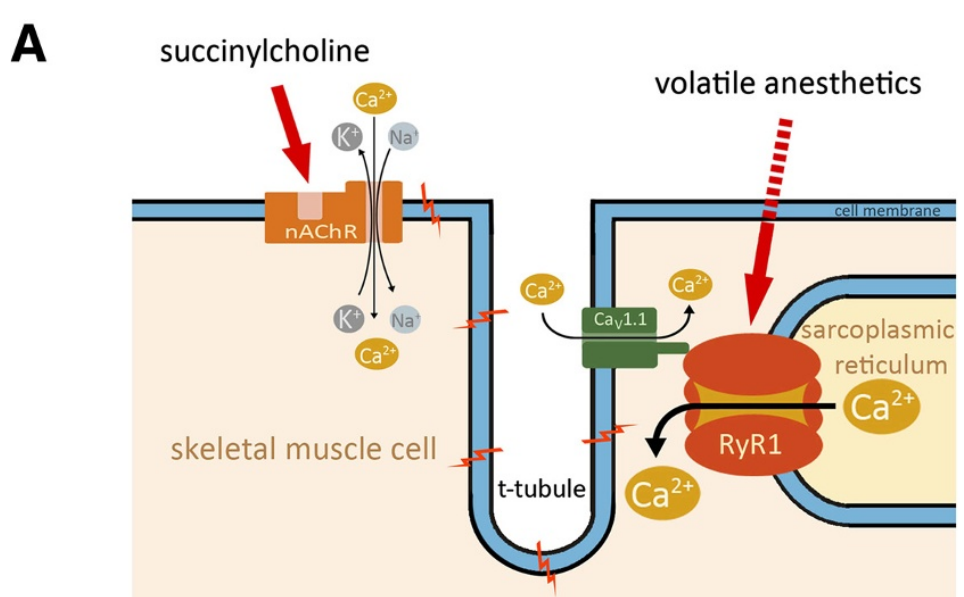

B
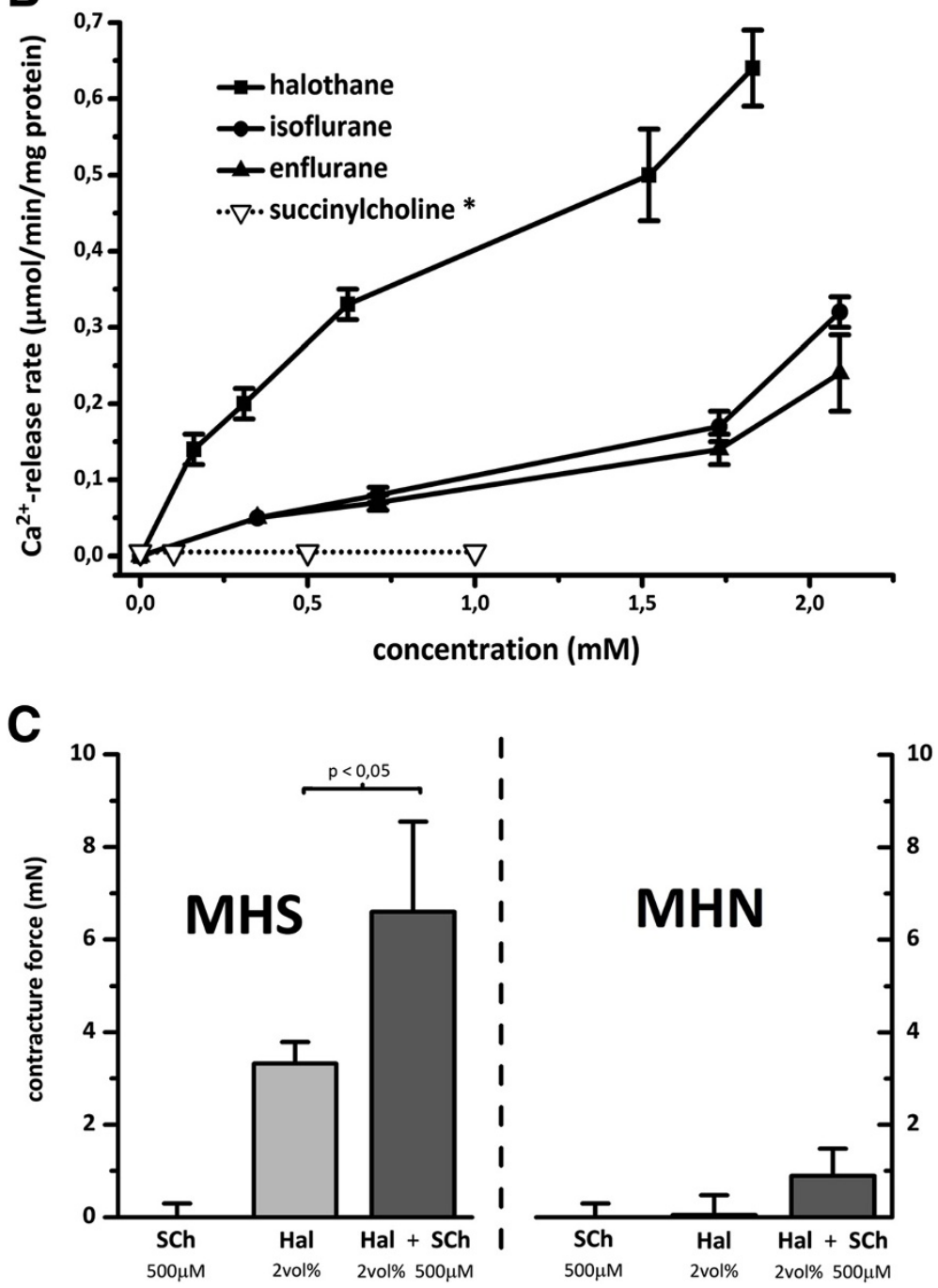

Figure 1 (See legend on next page.) 


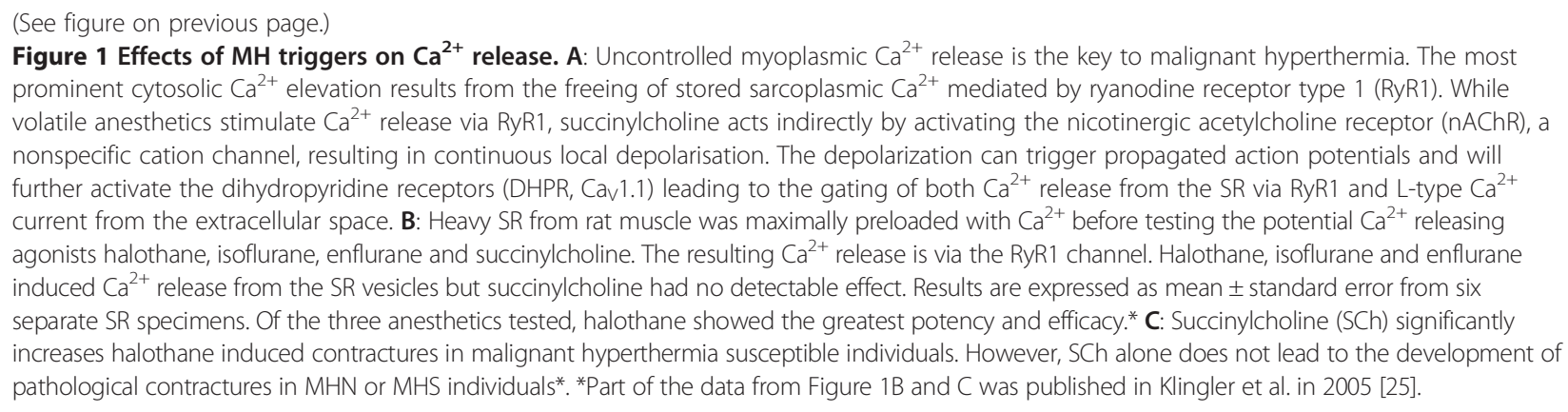

rigidity (process I: rigidity), maximum serum creatine kinase $(\mathrm{CK})$ or maximum serum myoglobin levels (process II: muscle breakdown), maximum $\mathrm{PaCO}_{2}$ (process III: respiratory acidosis), maximum temperature (process IV: temperature increase), tachycardia or ventricular arrhythmia (process V: cardiac involvement), negative base excess $(\mathrm{BE})$, arterial acidosis, and rapid reversal of $\mathrm{MH}$ signs after IV dantrolene (other indicators). The highest score of the processes noted are added together. The resulting raw scores are assigned as $\mathrm{MH}$ ranks which helps to predict the likelihood of an acute $\mathrm{MH}$ crisis: $\mathrm{MH}$ rank 1: "almost never", MH rank 2: "unlikely", MH rank 3: "somewhat less than likely", MH rank 4: "somewhat greater than likely", MH rank 5: "very likely" and $\mathrm{MH}$ rank 6: "almost certain". Only datasets were included in which all necessary parameters for the calculation of CGS were measured and available.

\section{In vitro contracture test}

Biopsies were taken from the vastus medialis or lateralis of the quadriceps muscle under regional anesthesia or triggerfree general anesthesia. The muscle specimens were used to perform IVCTs using the regularly revised protocol of the European Malignant Hyperthermia Group (EMHG) [16]. This test is used to determine the sensitivity of the skeletal muscle to caffeine and halothane which in turn allows assessment of the predisposition to $\mathrm{MH}$. The viable specimens were kept at $37^{\circ} \mathrm{C}, \mathrm{pH} 7.4$ in Krebs-Ringer solu-

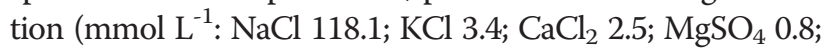
$\mathrm{KH}_{2} \mathrm{PO}_{4}$ 1.2; $\mathrm{NaHCO}_{3}$ 25.0; glucose 11.1) and dissected into individual strips $15 \mathrm{~mm}$ to $25 \mathrm{~mm}$ length, $2 \mathrm{~mm}$ to $3 \mathrm{~mm}$ in width and $100 \mathrm{mg}$ to $300 \mathrm{mg}$ in weight. Muscle strips with twitch amplitudes greater than $10 \mathrm{mN}$ to supramaximal electrical stimulation (pulse frequency of $0.2 \mathrm{~Hz}$; pulse width of $1 \mathrm{~ms}$ ), or a contracture of $\geq 50 \mathrm{mN}$ in the caffeine test in response to $32 \mathrm{mmol} \mathrm{L}^{-1}$ caffeine were considered viable. The force elicited was detected by a myoelectrical transducer (e.g. the FT03 from Grass Instruments, Quincy, MA). Pathological contractures were defined as having a threshold of $2 \mathrm{mN}$ occurring at concentrations of $2 \mathrm{mmol} \mathrm{L}^{-1}$ caffeine or less or $2 \%(\mathrm{v} / \mathrm{v})\left(0.44 \mathrm{mmol} \mathrm{L}^{-1}\right)$ halothane or less. Individuals with pathological contractures related to both caffeine and halothane were considered to be MH susceptible (MHS); patients whose specimens developed pathological contractures to only one test drug were considered to be $\mathrm{MH}$ equivocal (MHEc for caffeine positive, MHEh for halothane positive), and if no pathological contractures occurred at $2 \mathrm{mmol} \mathrm{L}^{-1}$ caffeine and $2 \%(\mathrm{v} / \mathrm{v})$ halothane the patient was classified as $\mathrm{MH}$ negative (MHN). Surplus tissue from muscle biopsy specimens of the Ulm MH unit was used in further analysis with the approval of the local ethics committee (Ethics Committee of Ulm University). The contracture forces following a pharmacological challenge with $500 \mu \mathrm{mol} \mathrm{SCh}, 2 \%(\mathrm{v} / \mathrm{v})$ halothane, and the combination of both substances was studied. Halothane was purchased from Zeneca (Planckstadt, Germany), and preservative-free SCh was purchased from Curamed Pharma (Karlsruhe, Germany). Further details are provided in Klingler et al. 2005 [25].

\section{Genetic screening}

Blood samples of the patients were genetically screened for RyR1 mutations of all 106 RYR1 exons and additionally for known mutations of CACNA1S. The CACNA1S gene encodes for the $\alpha 1$-subunit of the L-type $\mathrm{Ca}^{2+}$ channel $\mathrm{Ca}_{\mathrm{V}}$ 1.1. Briefly described, blood cells were haemolysed and then DNA was extracted and amplified by polymerase chain reaction for further analysis. Details of the method are described in Zullo et al. 2009 [26]. Three different prediction algorithms were used to estimate a possible impact of novel amino acid substitutions on structure and function of RyR1: SIFT (http://sift.jcvi.org/), Mutation taster (http://www.mutationtaster.org/), and Polyphen2 (http:// genetics.bwh.harvard.edu/pph2/).

\section{$\mathrm{Ca}^{2+}$ Release in isolated SR}

Heavy SR was prepared from hind limb muscles of rats as previously described [25,27]. $\mathrm{Ca}^{2+}$ release was measured by spectrophotometry using a HP 8452A diode-array spectrophotometer operating in dual wavelength mode at $710 \mathrm{~nm}$ and $790 \mathrm{~nm}$ at $37^{\circ} \mathrm{C}$ with constant magnetic cuvette stirring. Isolated SR was incubated with the $\mathrm{Ca}^{2+}$ chelometric dye antipyralazo III in a total volume of $2 \mathrm{ml}$ in a ground glass-stoppered glass cuvette using a medium containing 
$19 \mathrm{mmol} \mathrm{L}{ }^{-1}$ MOPS, $93 \mathrm{mmol} \mathrm{L}^{1-} \mathrm{KCl}, 7.5 \mathrm{mmol} \mathrm{L}^{-1}$ sodium pyrophosphate, $1 \mathrm{mmol} \mathrm{L}^{-1} \mathrm{MgATP}, 5 \mathrm{mmol} \mathrm{L}^{-1}$ creatine phosphate, $20 \mu \mathrm{g} / \mathrm{ml} \mathrm{CK}$ and $250 \mathrm{mmol} \mathrm{\textrm {L } ^ { - 1 }}$ antipyralazo III at $\mathrm{pH}$ 7.0. $\mathrm{Ca}^{2+}$ flux was monitored continuously over time, and when the SR was maximally loaded with $\mathrm{Ca}^{2+}$ potential releasing agents were added at varying concentrations to establish whether $\mathrm{Ca}^{2+}$ release occurred. Succinylcholine, halothane, isoflurane and enflurane were added to the cuvette from concentrated stock solutions made up in pure ethanol using a gas-tight micro-syringe. Controls showed that ethanol had no effect at the concentrations used. SR protein concentration was measured as previously reported [25,27]. Anesthetic concentrations in the cuvette reaction medium were analyzed using electron capture gas chromatography. The three anesthetics were first purified by distillation [27].

\section{Statistical analysis}

Results are presented as a mean with standard deviation. Discrete data are also provided as median and interquartile range ( $25 \%$ to $75 \%)$, black horizontal lines within the boxes show median values, whiskers indicate ranges and white squares represent mean values. Differences between the groups were assessed using the non-parametric Mann-Whitney U-test (also known as Wilcoxon ranksum test or Mann-Whitney-Wilcoxon) and results were interpreted as significant if $\mathrm{p}<0.05$.

\section{Results}

\section{Differing in vitro effects of volatile anaesthetics and succinylcholine}

In a first set of experiments, we investigated different subcellular action sites within muscle fibres (Figure 1A). We analysed isolated SR-vesicles and found that volatile anesthetics stimulate $\mathrm{SR}$ mediated $\mathrm{Ca}^{2+}$ release: Isolated heavy SR of rat muscle strips revealed a significant increase in $\mathrm{Ca}^{2+}$ after administration of halothane, isoflurane and enflurane. In contrast to the effects observed with volatile anesthetics, $\mathrm{SCh}$ did not affect $\mathrm{Ca}^{2+}$ release from isolated SR vesicles at concentrations of up to $1 \mathrm{mmol} \mathrm{L}^{-1}$ (Figure 1B). Myographic recordings show that preservative-free SCh at concentrations of up to $1 \mathrm{mmol} \mathrm{L}^{-1}$ does not evoke contractures in isolated muscle bundles. There was however a significant contracture increase when SCh was combined with halothane or caffeine (Figure 1C).

\section{Multi-centre evaluation}

Seven European MH test units participated in this multicentre evaluation. The data set included 263 patients. In total 63 of them had to be excluded from the study: 60 of these were due to incomplete initial clinical documentation, three of them because of possibly interfering comorbid factors: one being an intensive care patient with malaria and pneumonia, one being a polytrauma patient with hereditary sensorimotor neuropathy type 1 (CharcotMarie-Tooth disease) and one being a King-Denborough patient with a non-anesthetic event. The remaining 200 cases were included - 165 of them MHS and 35 MHE. These crises happened during the time period from 1972 to 2010; patients were subsequently transferred to one of the investigation units of this multi-centre study for diagnosis. In five patients central cores were identified histologically. All of them carried RyR1 mutations of unknown causality (p.R4735E, p.I2453T, p.I4138T, p.D60Y, p.E342K). The histological examination yielded non classifiable core like lesions in another patient. She carried the RyR1 mutation p.R44C and suffered a severe clinical crisis (CGS $=78$ points).

There was only one conclusive MHS patient whose $\mathrm{MH}$ crisis was triggered by SCh in the absence of volatile anesthetics. This 13 years old boy developed a masseter spasm and generalized muscle rigidity after induction with thiopental and intubation with SCh during ENT surgery; dantrolene was not given. He later showed a peak creatine kinase of 17,768 U/L. The calculated CGS was 15 points (rank 3: "somewhat less than likely"). The IVCT showed an abnormal reaction (MHS) and genetic analysis revealed a causative RyR1 mutation (p.R614C). Similarly one MHE patient was triggered by SCh alone: This 10 years old boy underwent emergency surgery because of testicular torsion. After application of SCh without pre-curarization clinical signs compatible with $\mathrm{MH}$ were masseter spasm and increased body temperature $\left(40^{\circ} \mathrm{C}\right)(\mathrm{CGS}=25$ points, rank 4 "somewhat greater than likely"). The IVCT was

Table 1 Multicenter evaluation of triggering potency

\begin{tabular}{|c|c|c|c|c|}
\hline \multirow[t]{3}{*}{ Trigger } & \multirow{2}{*}{\multicolumn{2}{|c|}{ No. of patients }} & \multicolumn{2}{|c|}{ Clinical grading scale } \\
\hline & & & \multicolumn{2}{|c|}{ (raw score) } \\
\hline & MHS & MHE & MHS & MHE \\
\hline Vol. anesthetics & 30 & 6 & $40.5(28.5-61.0)$ & $34.0(30.8-41.0)$ \\
\hline $\mathrm{SCh}$ & 1 & 1 & 15 & 25 \\
\hline Vol. anesthetics + SCh & 134 & 28 & $43.0(30.0-55.0)$ & $33.0(15.0-40.0)$ \\
\hline Total & 165 & 35 & $43.0(30.0-55.8)$ & $33.0(19.0-40.0)$ \\
\hline
\end{tabular}

The vast majority of the cases were triggered by the combination of volatile anesthetics and succinylcholine (SCh). Remarkable only one MHS case was triggered by SCh alone, along with one MHE case. The clinical grading scale according to Larach et al. 1994 classifies a raw score of more than 35 as very likely to be clinical $\mathrm{MH}$. Data are shown as median and interquartile range $(25 \%-75 \%)$. 

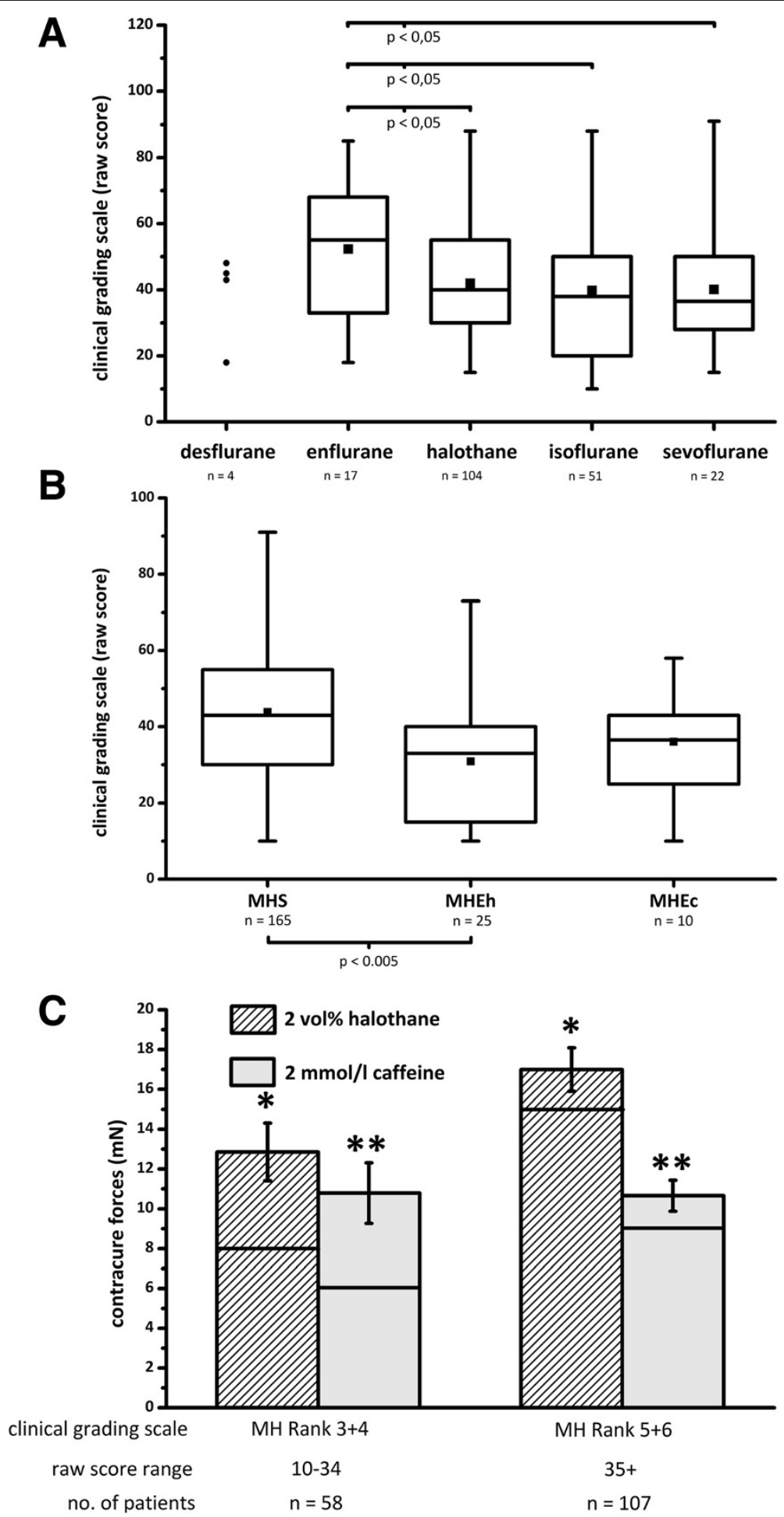

Figure 2 Clinical effects of volatile anesthetics. A: Box and whisker plots showing clinical grading scales (CGS) of 200 malignant hyperthermia susceptible (MHS, $n=165)$ or equivocal $(M H E, n=35)$ patients depending on the anesthetic agent used. Enflurane developed a significantly higher CGS compared to halothane, isoflurane and sevoflurane. B: CGS depending on the in vitro contracture test results: malignant hyperthermia susceptible (MHS), malignant hyperthermia equivocal halothane positive (MHEh) and caffeine positive (MHEc). A Mann-Whitney U-test was performed and yielded significant differences between MHS vs. MHEh, i.e. MHS vs. (MHEh + MHEc). C: Patients in this study with clinical crises that resulted in high MH Ranks (5 and 6) developed greater halothane and caffeine contractures than patients with lower MH Ranks (3 and 4). Asterisks (*, **) indicate significant differences. Columns represent mean \pm standard error of the mean and black horizontal lines within the columns show median values. 
abnormal for caffeine (MHEc); no RyR1 mutation was detected.

In the majority $(\mathrm{MHS}=81 \%, \mathrm{MHE}=80 \%)$ both volatile anesthetics and SCh were administered. In the other cases $(\mathrm{MHS}=18 \%, \mathrm{MHE}=17 \%)$ patients had received volatile anesthetics alone (Table 1). A Mann-Whitney U-test was performed which showed no significant difference in the raw score of CGS between patients who received volatile anesthetics alone and those who received volatile anesthetics plus SCh. The enflurane subgroup showed a significantly higher CGS compared to halothane, isoflurane and sevoflurane (Figure 2A).The age of the halothane group $(10.5 \pm 10.4)$ was significantly younger compared to the age of those receiving desflurane $(40.5 \pm 18.7)$, enflurane $(19.7 \pm 11.1)$, isoflurane $(27.2 \pm 15.6)$ and sevoflurane $(20.5 \pm 12.8)$. Patients classified as MHS showed a significantly higher CGS $(43.8 \pm 19.6)$ compared to those tested MHE $(32.3 \pm 14.5)$ (Figure $2 \mathrm{~B})$, even though the distribution of halothane and enflurane cases were similar in both subgroups (halothane 6.07 vs. enflurane 6.33). The IVCT and CGS results showed consistent results: $\mathrm{MH}$ ranks 5 and 6 developed significantly higher contractures and significantly lower thresholds compared to $\mathrm{MH}$ ranks 3 and 4. (Figure 2C). Half of the patients (50\%) were younger than 12 years old at the time of crises and males $(70 \%)$ were more often affected than females (30\%) (Figure 3), however the CGS and the IVCT parameters did not differ significantly between males and females or adults and children.

\section{Genetic evaluation}

The overall RyR1 variant detection rate was 52\%; 51 different RyR1 mutations were detected in 101 patients (Table 2). Four patients carried two RyR1 mutations (Table 3). Overall 14 new RyR1 variants are described in this study. Results of SIFT, Mutation taster and Polyphen 2 analysis is shown in Tables 2 and 3. Two patients carried RyR1 polymorphisms: exon 15, c.1655G > A, p.R552Q (new variant, personal communication with V. Sorrentino) and exon 38, c.6178G > T, p.G2060C [6] which occurs in $6 \%$ of the European population according to GeneCards. One MHS patient showed a nonsense mutation in exon 103 (c.14833C > T, p.R4945X, novel variant, K. Jurkat-Rott). Stop codon mutations like R4945X have been identified in several MH families but they never segregated with the MHS status in the given family. One patient showed a $\mathrm{Ca}_{\mathrm{v}} 1.1$ mutation (exon 4, c.520C > T, p.R174W); further statistical analysis was therefore not possible. Four patients did not give permission for genetic screening and therefore had to be excluded from genetic analyses. Most of the RyR1 mutations were found inside the "hot spots" (MH/ CCD regions 1, 2 and 3) (Figure 4A). The halothane and caffeine contractures were both significantly higher if the mutation was found in one of these hot spots. Consistently, the thresholds of both test substances were significantly lower in hot spot mutations and these patients showed higher raw scores in the CGS (Figure 4B,C).

Patients with causative RyR1 mutations (as defined by EMHG) developed greater contractures, lower thresholds and higher raw scores in the CGS compared to patients with RyR1 mutations of unknown causality; however despite obvious caffeine contractures, no significant differences were detected between patients with mutations of unknown causality and patients without a RyR1 mutation (Table 4). In 8 of 35 MHE patients, an RyR1 mutation has been identified.

\section{Discussion}

\section{Age and gender preponderance}

The CGS was designed as an indicator for the likelihood that a given anesthetic crisis is $\mathrm{MH}$. However, if the anesthetist recognized the crisis early and consequently started treatment, the crisis might result in a deceptively low CGS. There may be other factors (e.g. hormonal effects) that influence the risk of developing an acute $\mathrm{MH}$ episode. Our result resembles in part the findings of Islander et al. 2007 [8] and Green Larach et al. 2010 [52]: children (50\%) and males (70\%) dominate the case numbers, although results of IVCT and CGS did not differ between males and females.

\section{RyR1 mutations}

At present there are more than 300 single nucleotide polymorphisms of the RyR1 known, while only 31 variants are functionally characterized as $\mathrm{MH}$ causative (www.emhg.org). The severity of IVCT varies between individuals with different RYR1 mutations [53]. In this study we confirm these findings and provide evidence that the RYR1 variants also vary in the severity of the clinical MH episodes: the clinical events were significantly

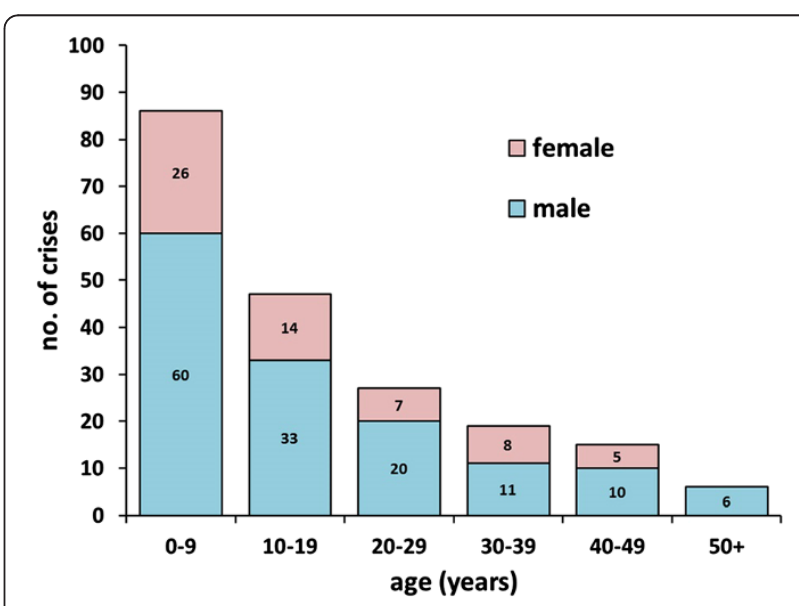

Figure 3 Age and gender preponderance. Age and gender of $200 \mathrm{MH}$ patients at the time of the clinical MH-episode. 
In vitro contracture test

\begin{tabular}{|c|c|c|c|c|c|c|c|c|c|c|c|c|c|}
\hline \multirow[b]{3}{*}{ Exon } & \multirow[b]{3}{*}{ Nucleotide } & \multirow[b]{3}{*}{ Substitution } & \multirow[b]{3}{*}{$\begin{array}{l}\text { No. of patients } \\
\text { in this study }\end{array}$} & & \multirow[b]{3}{*}{$\begin{array}{l}\text { Clinical } \\
\text { grading scale }\end{array}$} & \multirow[b]{3}{*}{$\begin{array}{l}\text { Causative } \\
\text { mutation? }\end{array}$} & \multirow[b]{3}{*}{$\begin{array}{l}\text { PolyPhen2 } \\
\text { predictions }\end{array}$} & \multirow[b]{3}{*}{$\begin{array}{l}\text { Sift } \\
\text { predictions }\end{array}$} & \multirow[b]{3}{*}{$\begin{array}{l}\text { Mutation } \\
\text { Taster } \\
\text { predictions }\end{array}$} & \multirow[b]{3}{*}{ Reference } \\
\hline & & & & \multicolumn{2}{|c|}{ Contracture } & \multicolumn{2}{|c|}{ Threshold } & & & & & & \\
\hline & & & & $\begin{array}{l}2 \text { vol\% } \\
\text { halothane }[\mathrm{mN}]\end{array}$ & $\begin{array}{l}2 \mathrm{mmoll}^{-1} \\
\text { caffeine [mN] }\end{array}$ & $\begin{array}{l}\text { Halothane } \\
\text { [vol\%] }\end{array}$ & $\begin{array}{l}\text { Caffeine } \\
{\left[\text { mmoll }^{-1}\right]}\end{array}$ & & & & & & \\
\hline 2 & c. $130 C>T$ & p.R44C & 1 & 12.0 & 10.8 & 0.5 & 1.0 & 78.0 & No & & & & $\begin{array}{l}\text { Tammaro et al. } \\
2003 \text { [28] }\end{array}$ \\
\hline 3 & c. $178 \mathrm{G}>\mathrm{T}$ & p.D60Y & 1 & 13.0 & 4.5 & 1.0 & 2.0 & 30.0 & No & + & + & + & $\begin{array}{l}\text { This study, } \\
\text { V. Sorrentino }\end{array}$ \\
\hline 11 & c. $1021 \mathrm{G}>\mathrm{A}$ & p.G341R & 3 & $14.3 \pm 4.8$ & $13.7 \pm 3.1$ & $0.8 \pm 0.2$ & $0.8 \pm 0.5$ & $54.3 \pm 4.9$ & Yes & & & & Quane et al. 1994 [29] \\
\hline 11 & c. $1024 \mathrm{G}>\mathrm{A}$ & p.E342K & 1 & 37.8 & 23.8 & 0.5 & 0.5 & 30.0 & No & + & + & + & $\begin{array}{l}\text { This study, } \\
\text { K. Jurkat-Rott }\end{array}$ \\
\hline 11 & C.1100G $>A$ & p.R367Q & 1 & 10.0 & 4.1 & 0.5 & 1.5 & 15.0 & No & & & & Galli et al. 2006 [30] \\
\hline 12 & c. $1201 C>T$ & p.R401C & 1 & 17.0 & 7.0 & 1.0 & 1.5 & 18.0 & No & & & & Davis et al. 2002 [31] \\
\hline 12 & c. $1202 \mathrm{G}>\mathrm{A}$ & p.R401H & 1 & 21.0 & 12.0 & 1.0 & 1.5 & 55.0 & No & & & & Rüffert et al. 2002 [32] \\
\hline 15 & c. $1655 \mathrm{G}>\mathrm{A}$ & p.R552Q* & 1 & 36.0 & 8.0 & 0.5 & 1.5 & 38.0 & No & + & - & + & $\begin{array}{l}\text { This study, } \\
\text { V. Sorrentino }\end{array}$ \\
\hline 17 & c. $1840 C>T$ & p.R614C & 25 & $13.7 \pm 8.9$ & $10.5 \pm 8.3$ & $0.9 \pm 0.5$ & $1.3 \pm 0.7$ & $50.8 \pm 22.3$ & Yes & & & & Gillard et al. 1992 [33] \\
\hline 17 & c. $1841 \mathrm{G}>\mathrm{T}$ & p.R614L & 2 & $16.6 \pm 2.6$ & $8.3 \pm 2.3$ & $0.5 \pm 0.0$ & $1.0 \pm 0.5$ & $30.5 \pm 2.5$ & Yes & & & & Quane et al. 1997 [34] \\
\hline 34 & $c .5011 \mathrm{G}>\mathrm{A}$ & p.A1671T & 1 & 8.0 & 24.8 & 2.0 & 0.5 & 35.0 & No & + & + & - & $\begin{array}{l}\text { This study, } \\
\text { K. Jurkat-Rott }\end{array}$ \\
\hline 38 & c.6178G $>T$ & p.G2060C* & 1 & 16.4 & 8.0 & 0.5 & 1.0 & 88.0 & No & & & & Robinson et al. 2006 [6] \\
\hline 39 & c. $6377 \mathrm{G}>\mathrm{A}$ & p.R2126Q & 1 & 26.8 & 8.8 & 0.5 & 2.0 & 35.0 & No & & & & Kraeva et al. 2011 [7] \\
\hline 39 & c. $6387 C>G$ & p.D2129E & 1 & 10.0 & 11.0 & 2.0 & 1.0 & 45.0 & No & & & & Rüffert et al. 2001 [35] \\
\hline 39 & c. $6488 \mathrm{G}>\mathrm{C}$ & p.R2163P & 1 & 20.0 & 4.0 & 1.0 & 2.0 & 55.0 & No & & & & $\begin{array}{l}\text { Robinson et al. } \\
2006 \text { [6] }\end{array}$ \\
\hline 39 & c. $6502 \mathrm{G}>\mathrm{A}$ & p.V2168M & 6 & $22.5 \pm 7.1$ & $12.3 \pm 5.0$ & $0.5 \pm 0.0$ & $1.1 \pm 0.3$ & $58.8 \pm 20.5$ & Yes & & & & $\begin{array}{l}\text { Manning et al. } \\
1998 \text { [36] }\end{array}$ \\
\hline 40 & c. $6599 \mathrm{C}>\mathrm{T}$ & p.A2200V & 1 & - & 3.0 & - & 2.0 & 10.0 & No & & & & $\begin{array}{l}\text { Sambuughin et al. } \\
2005 \text { [37] }\end{array}$ \\
\hline 40 & c. $6617 \mathrm{C}>\mathrm{T}$ & p.T2206M & 9 & $20.5 \pm 10.7$ & $10.4 \pm 4.9$ & $0.9 \pm 0.4$ & $1.0 \pm 0.4$ & $50.4 \pm 16.2$ & Yes & & & & $\begin{array}{l}\text { Manning et al. } \\
1998 \text { [36] }\end{array}$ \\
\hline 41 & c. $6710 \mathrm{G}>\mathrm{A}$ & p.C2237Y & 1 & 6.0 & 6.0 & 0.5 & 1.0 & 38.0 & No & + & + & + & $\begin{array}{l}\text { This study, } \\
\text { M. Snoeck }\end{array}$ \\
\hline 43 & c. $7007 \mathrm{G}>\mathrm{A}$ & p.R2336H & 4 & $12.8 \pm 4.5$ & $11.7 \pm 6.1$ & $0.8 \pm 0.3$ & $1.1 \pm 0.2$ & $47.3 \pm 4.4$ & No & & & & Levano et al. 2009 [38] \\
\hline 43 & c. $7025 \mathrm{~A}>\mathrm{G}$ & p.N2342S & 1 & 3.0 & 0.0 & 2.0 & 4.0 & 30.0 & No & & & & $\begin{array}{l}\text { Marchant et al. } \\
2004 \text { [39] }\end{array}$ \\
\hline 44 & c.7034G >C & p.S2345T & 1 & 32.0 & 24.0 & 0.5 & 1.0 & 28.0 & No & $(+)$ & - & + & $\begin{array}{l}\text { This study, } \\
\text { V. Sorrentino }\end{array}$ \\
\hline
\end{tabular}


Table 2 Mutations of ryanodine receptor type 1 (Continued)

\begin{tabular}{|c|c|c|c|c|c|c|c|c|c|c|c|c|c|}
\hline 44 & c.7048G $>A$ & p.A2350T & 1 & 22.0 & 9.0 & 1.0 & 1.0 & 55.0 & Yes & & & & $\begin{array}{l}\text { Sambuughin } \\
\text { et al. } 2001 \text { [40] }\end{array}$ \\
\hline 44 & c.7076G >A & p.R2359Q & 1 & 3.0 & 4.0 & 2.0 & 2.0 & 15.0 & No & $(+)$ & - & + & This study, H. Rüffert \\
\hline 44 & c. $7085 A>G$ & p.E2362G & 1 & 16.0 & 8.0 & 0.5 & 1.0 & 43.0 & No & & & & Galli et al. 2006 [30] \\
\hline 44 & c. $7112 A>G$ & p.E2371G & 1 & 16.0 & 10.0 & 1.0 & 1.5 & 91.0 & No & & & & Zullo et al. 2009 [26] \\
\hline 44 & $c .7124 G>C$ & p.G2375A & 2 & $19.5 \pm 0.5$ & $20.5 \pm 1.5$ & $0.5 \pm 0.0$ & $0.8 \pm 0.3$ & $59.5 \pm 11.5$ & Yes & & & & Rüffert et al. 2002 [41] \\
\hline 45 & $c .7300 G>A$ & p.G2434R & 5 & $24.3 \pm 14.4$ & $12.2 \pm 8.2$ & $0.7 \pm 0.2$ & $1.1 \pm 0.6$ & $57.4 \pm 19.9$ & Yes & & & & $\begin{array}{l}\text { Sambuugghin } \\
\text { et al. } 2001 \text { [42] }\end{array}$ \\
\hline 46 & $c .7354 C>T$ & p.R2452W & 1 & 8.0 & 20.0 & 1.0 & 1.5 & 48.0 & No & & & & Chamley et al. 2000 [43] \\
\hline 46 & c.7358T>C & p.12453T & 1 & 7.0 & 7.0 & 1.0 & 1.5 & 63.0 & No & & & & Rüffert et al. 2002 [41] \\
\hline 46 & $c .7360 C>T$ & p.R2454C & 1 & 9.2 & 6.0 & 0.5 & 1.0 & 28.0 & Yes & & & & Brandt et al. 1999 [44] \\
\hline 46 & c. $7361 \mathrm{G}>\mathrm{A}$ & p.R2454H & 3 & $15.3 \pm 5.7$ & $13.0 \pm 6.5$ & $0.8 \pm 0.2$ & $1.0 \pm 0.4$ & $48.0 \pm 12.2$ & Yes & & & & Barone et al. 1999 [45] \\
\hline 46 & c. $7372 C>T$ & p.R2458C & 2 & $7.3 \pm 1.3$ & $2.0 \pm 1.0$ & $1.0 \pm 0.0$ & $2.0 \pm 0.0$ & $41.5 \pm 31.5$ & Yes & & & & Manning et al. 1998 [46] \\
\hline 71 & c. $10616 G^{\prime} A$ & p.R3539H & 1 & 7.0 & 8.0 & 2.0 & 1.5 & 38.0 & No & & & & $\begin{array}{l}\text { Dekomien et al. } \\
2005 \text { [47] }\end{array}$ \\
\hline 85 & c. $11708 \mathrm{G}>\mathrm{A}$ & p.R3903Q & 2 & $4.8 \pm 0.2$ & $2.5 \pm 0.5$ & $2.0 \pm 0.0$ & $2.0 \pm 0.0$ & $25.0 \pm 5.0$ & No & & & & Galli et al. 2006 [30] \\
\hline 85 & c. $11723 \mathrm{~A}>\mathrm{T}$ & p.N3908I & 1 & 8.0 & 4.8 & 1.0 & 1.5 & 20.0 & No & + & + & + & $\begin{array}{l}\text { This study, } \\
\text { K. Jurkat-Rott }\end{array}$ \\
\hline 90 & c. $12398 \mathrm{~A}>\mathrm{G}$ & p.E4133G & 1 & 2.0 & 2.5 & 2.0 & 2.0 & 10.0 & No & + & + & + & $\begin{array}{l}\text { This study, } \\
\text { V. Sorrentino }\end{array}$ \\
\hline 90 & c. $12413 \mathrm{~T}>\mathrm{C}$ & p.14138T & 1 & 11.0 & 15.0 & 1.0 & 1.0 & 25.0 & No & & & & Robinson et al. 2006 [6] \\
\hline 90 & c. $12532 \mathrm{G}>\mathrm{A}$ & p.G4178S & 1 & 32.0 & 8.0 & 0.5 & 1.5 & 38.0 & No & + & + & + & $\begin{array}{l}\text { This study, } \\
\text { V. Sorrentino }\end{array}$ \\
\hline 95 & c.13990T>C & p.C4664R & 1 & 20.0 & 4.0 & 1.5 & 1.5 & 50.0 & No & & & & Zullo et al. 2009 [26] \\
\hline 98 & c. $14204 G>A$ & p.R4735Q & 1 & 7.0 & 5.0 & 1.0 & 1.5 & 50.0 & No & + & - & + & This study, H. Rüffert \\
\hline 101 & c. $14545 G>A$ & p.V4849| & 3 & $3.8 \pm 3.1$ & $3.3 \pm 0.8$ & $1.5 \pm 0.5$ & $2.0 \pm 0.0$ & $36.3 \pm 8.5$ & No & & & & $\begin{array}{l}\text { Jungbluth } \\
\text { et al. } 2002 \text { [48] }\end{array}$ \\
\hline 101 & c. $14627 A>G$ & p.K4876R & 1 & 14.0 & 14.0 & 0.5 & 0.5 & 48.0 & No & & & & $\begin{array}{l}\text { Monnier et al. } 2005 \\
\text { [49] }\end{array}$ \\
\hline 103 & c. $14833 C>T$ & p.R4945X & 1 & 9.9 & 23.3 & 0.5 & 0.5 & 15.0 & No & na & na & + & $\begin{array}{l}\text { This study, } \\
\text { K. Jurkat-Rott }\end{array}$ \\
\hline 106 & c. $15059 \mathrm{G}>\mathrm{C}$ & p.W5020S & 1 & 1.0 & 2.0 & - & 2.0 & 43.0 & No & + & + & + & $\begin{array}{l}\text { This study, } \\
\text { V. Sorrentino }\end{array}$ \\
\hline
\end{tabular}

Overview of all ryanodine receptor type 1 (RyR1) mutations that have been detected in this study. If more than one patient carried the same mutation results of in vitro contracture tests (IVCT) and clinical grading scales are shown as mean \pm standard deviation. Patients with double RyR1 mutations are listed separately. Novel variations $(n=13)$ are highlighted $($ bold). Polymorphisms $(n=2)$ are marked with asterisks $(*)$.

Polyphen2: $+=$ probably damaging,$(+)=$ possibly damaging, $-=$ benign, $\mathbf{n a}=$ not applicable to truncations; Sift: $+=$ deleterious, $-=$ tolerated, $\mathbf{n a}=$ not applicable to truncations; Mutation taster:

$+=$ disease-causing; - = polymorphism. 
Table 3 Double mutations of the ryanodine receptor type 1

\begin{tabular}{|c|c|c|c|c|c|c|c|c|c|c|c|c|c|}
\hline \multirow[b]{3}{*}{$\begin{array}{l}\text { No. of patients } \\
\text { in this study }\end{array}$} & \multirow[b]{3}{*}{ Exon } & \multirow[b]{3}{*}{ Nucleotide } & \multirow[b]{3}{*}{ Substitution } & \multirow[b]{3}{*}{$\begin{array}{l}\text { Causative } \\
\text { mutation? }\end{array}$} & \multirow[b]{3}{*}{$\begin{array}{l}\text { PolyPhen2 } \\
\text { predictions }\end{array}$} & \multirow[b]{3}{*}{$\begin{array}{l}\text { Sift } \\
\text { predictions }\end{array}$} & \multirow[b]{3}{*}{$\begin{array}{l}\text { Mutation taster } \\
\text { predictions }\end{array}$} & \multirow[b]{3}{*}{ References } & \multicolumn{4}{|c|}{ In vitro contracture test } & \multirow[b]{3}{*}{ CGS } \\
\hline & & & & & & & & & \multicolumn{2}{|c|}{ Contracture } & \multicolumn{2}{|c|}{ Threshold } & \\
\hline & & & & & & & & & $\begin{array}{l}2 \text { vol\% } \\
\text { halothane }[\mathrm{mN}]\end{array}$ & $\begin{array}{l}2 \mathrm{mmoll}^{-1} \\
\text { caffeine }[\mathrm{mN}]\end{array}$ & $\begin{array}{l}\text { halothane } \\
\text { [vol\%] }\end{array}$ & $\begin{array}{l}\text { caffeine } \\
{\left[\text { mmoll }^{-1}\right]}\end{array}$ & \\
\hline \multirow[t]{2}{*}{1} & 11 & c. $1100 \mathrm{G}>\mathrm{T}$ & p.R367L & No & + & - & + & This study, T. Girard & 20.0 & 4.5 & 1.0 & 1.5 & 48 \\
\hline & 65 & c.9649T>C & p.S3217P & No & & & & Levano et al. 2009 [38] & & & & & \\
\hline \multirow[t]{2}{*}{1} & 8 & c.677T $>A$ & p.M226K & No & & & & Robinson et al. 2006 [6] & 53.0 & 24.0 & 0.5 & 0.5 & 38 \\
\hline & 28 & c. $4024 A>G$ & p.S1342G & No & & & & Levano et al. 2009 [39] & & & & & \\
\hline \multirow[t]{2}{*}{1} & 44 & c. $7085 \mathrm{~A}>\mathrm{G}$ & p.E2362G & No & & & & Galli et al. 2006 [30] & 56.0 & 57.0 & 0.5 & 0.5 & 35 \\
\hline & 93 & C.13513G>C & p.D4505H & No & & & & Groom et al. 2011 [50] & & & & & \\
\hline \multirow[t]{2}{*}{1} & 29 & C. $4178 \mathrm{~A}>\mathrm{G}$ & p.K1393R & No & & & & Vukcevic et al. 2010 [51] & 15.0 & 12.0 & 0.5 & 1.5 & 35 \\
\hline & 98 & c. $14210 \mathrm{G}>\mathrm{A}$ & p.R4737Q & No & & & & Monnier et al. 2005 [49] & & & & & \\
\hline
\end{tabular}

In this study four patients carried a double mutation of the ryanodine receptor type 1 (RyR1). These patients had marked outcomes in the in vitro contracture tests but clinical grading scales were avarage (mean: 39.00 points). Due to the small number of cases a statistical analysis was not performed. Novel mutations $(n=1)$ are highlighted (bold). CGS = clinical grading scale. 

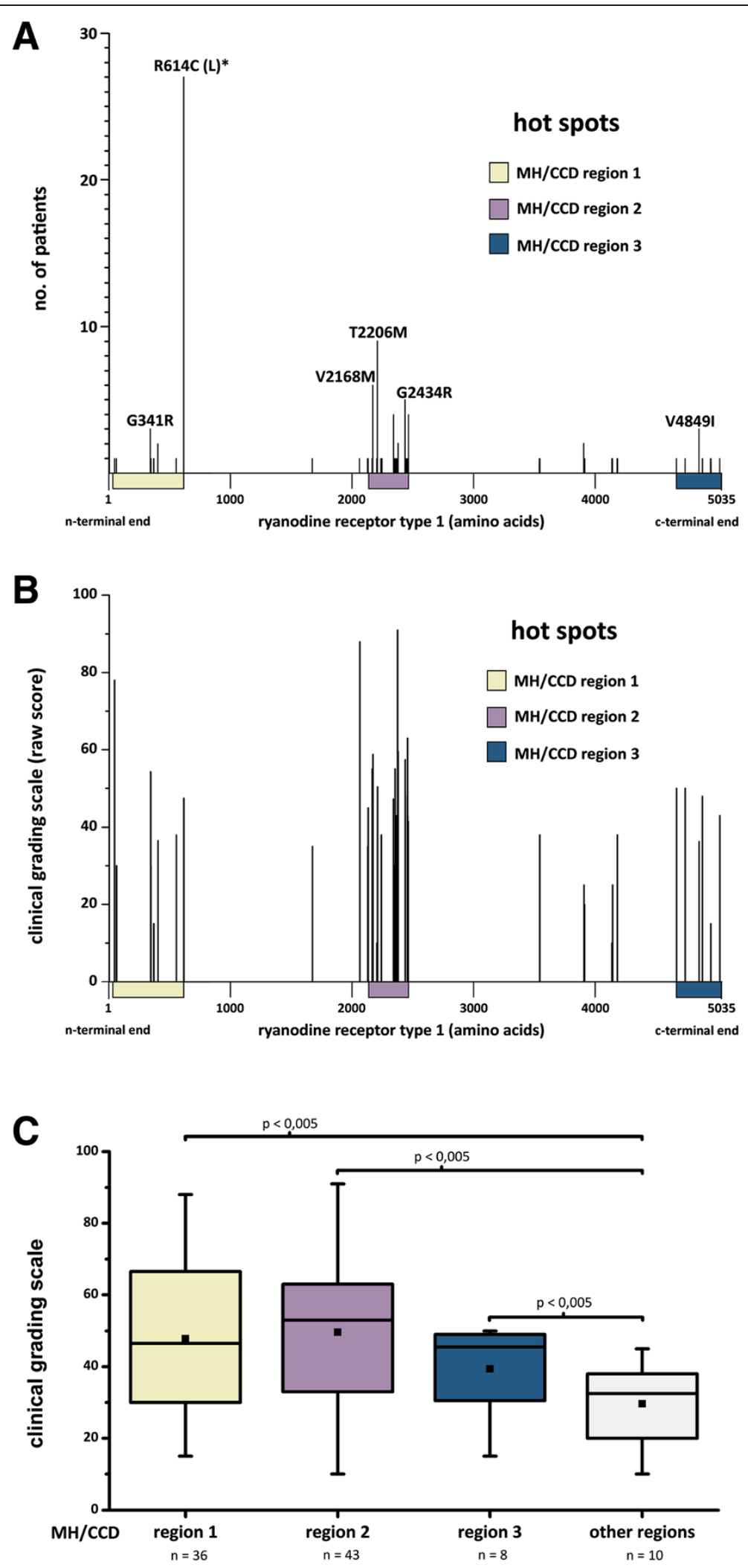

Figure 4 (See legend on next page.) 
more severe in patients suffering from mutations inside $\mathrm{MH} / \mathrm{CCD}$ regions 1, 2 and 3. SIFT, Mutation taster and Polyphen2 were used to characterize the relevance of novel RyR1 variants. All three prediction algorithms favour a possible effect on the protein function for the amino acid substitutions p.D60Y, p.E342K, p.C2237Y, p.N3908I, p.E4133G, p.G4178S and p.W5020S. Therefore a causative association to $\mathrm{MH}$ is likely. However, functional $\mathrm{Ca}^{2+}$ release experiments are needed to confirm gain of RyR1 function needed for $\mathrm{MH}$ susceptibility. Including the 14 novel RyR1 variants, 38 patients carried RyR1 mutations that have not yet been functionally analyzed. Those variants of unknown causality did develop less severe $\mathrm{MH}$ crises compared to functional analyzed causative mutations. Interestingly, mutations of unknown causality did not differ in the CGS compared to patients with wild-type RyR1. The RyR1 mutation p.R4945X is unlikely to cause MH because it results in a non-functional protein product rather than a gain-of-function as required for causative $\mathrm{MH}$ Mutations.

\section{Volatile anesthetics}

In this study enflurane produced the highest CGS: the differences compared to halothane, isoflurane and sevoflurane were significant. However, this tendency was not found in other studies $[14,15]$ and might be biased by differential handling of the crises such as the rapidness of dantrolene administration. Most crises were triggered by halothane. This might be influenced by the fact that halothane has been in use over the longest time span. On the other hand, patients in this study who received halothane were significantly younger compared to those who received other volatile anesthetics. At this point the patient's age can be considered to be confounding variable; even though the CGS did not differ between age groups. As a result, the high number of halothane cases may not lead to any conclusion regarding its relative triggering potency. Still, in rat muscle halothane was significantly more likely to cause RyR1 mediated $\mathrm{Ca}^{2+}$ release than enflurane. In the literature, halothane is almost uniformly considered to be the most potent MH trigger [9-13]. Nonetheless, using the onset time of clinical symptoms Allen et al. did not find significant differences between halothane and desflurane when analyzing 365 unconfirmed crises from the American MH registry [14], and similarly Hopkins did not find significant differences between halothane and isoflurane in 75 cases confirmed by a positive IVCT [15]. Furthermore the relative triggering potencies of the other volatile anesthetics vary markedly in the above cited publications.

MH crises triggered by desflurane are described but seem to happen rarely: for example during the years 1990 to 2005 , only two such cases were referred to the UK MH unit in Leeds [15]. In our study, we note four additional desflurane crises (CGS raw score $=38.5 \pm 12.0$ ), each confirmed by an MHS result in the IVCT.

\section{Succinylcholine}

SCh activates the $\mathrm{nAChR}$ which depolarizes the muscle membrane by acting as an ion channel permeable to $\mathrm{K}^{+}$, $\mathrm{Na}^{+}$and also $\mathrm{Ca}^{2+}$ [54]. The depolarisation triggers propagated action potentials initially; these rapidly cease due to the refractoriness. The remaining nAChR-mediated depolarization spreads some distance electrically along the fibre axis depending on the fibre's cable properties. In the $\mathrm{t}$-tubules, it activates the DHPRs (Cav 1.1$)$ which may lead to both entry of $\mathrm{Ca}^{2+}$ from the extracellular space and (through mechanical coupling) opening of the RyR1 along with $\mathrm{Ca}^{2+}$ release [55]. Whereas $\mathrm{SCh}$ action activates the

Table 4 Effect of causative ryanodine receptor type 1 mutation

\begin{tabular}{|c|c|c|c|c|c|}
\hline \multirow{2}{*}{$\begin{array}{l}\text { Classification of } \\
\text { RyR1 mutation }\end{array}$} & \multirow{2}{*}{$\begin{array}{l}\text { Clinical } \\
\text { grading scale }\end{array}$} & \multicolumn{2}{|c|}{ Contracture $(\mathrm{mN})$} & \multicolumn{2}{|c|}{ Threshold } \\
\hline & & 2 vol\% halothane & $2 \mathrm{mmol} \mathrm{I}^{-1}$ caffeine & halothane (vol\%) & Caffeine $\left(\mathrm{mmol} \mathrm{l}^{-1}\right)$ \\
\hline Causative & $51.10 \pm 20.67^{*}+$ & $16.77 \pm 9.84+*$ & $10.94 \pm 7.24 *$ & $0.81 \pm 0.44+*$ & $1.14 \pm 0.63+*$ \\
\hline Unknown causality & $38.08 \pm 17.46^{*}$ & $11.69 \pm 8.99 *$ & $8.73 \pm 6.90^{*}$ & $1.10 \pm 0.58^{*}$ & $1.50 \pm 0.64^{*}$ \\
\hline None detected & $37.55 \pm 16.90+$ & $11.43 \pm 10.90+$ & $7.52 \pm 10.02^{*}$ & $1.30 \pm 0.83+$ & $2.35 \pm 7.70+$ \\
\hline
\end{tabular}

Causative ryanodine receptor type 1 (RyR1) mutations yield greater contractures, lower thresholds and higher raw score in the clinical grading scale (CGS). Results of 189 patients are shown as mean \pm standard deviation, Mann-Whitney $U$ test was performed and significant differences $(p<0.05$.) were marked with asterisk $(*)$ and cross $(+)$. Despite caffeine contractures there were no significant differences between unknown causality vs. none detected. RyR1 polymorphisms $(n=2)$, double RyR1 mutations $(n=4)$ and Cav1.1 mutations $(n=1)$ are not included in this table. 
excitation-contraction coupling pathway, volatile anesthetics cross the membrane and stimulate RyR1. In rat muscle volatile anesthetics were able to induce RyR1 mediated $\mathrm{Ca}^{2+}$ release, but not SCh [25]. Surprisingly we did not observe differences in the CGS of crises triggered by a $\mathrm{SCh}$ only versus SCh and volatile anesthetics. However the onset of $\mathrm{MH}$ crises was significantly faster when volatile anesthetics were combined with SCh [56]. The fact that we observed a SCh associated clinical crisis in the absence of volatile anesthetics does not prove $\mathrm{MH}$ triggering because undetected genetic variations or conditions explaining SCh hypersensitivity cannot be excluded.

Still, a recent study revealed that in more than $50 \%$ of the suspected MH crises in North America usage of SCh was recorded, while SCh was present in only $5 \%$ to $10 \%$ of all anesthetic records. Although this study was investigating unconfirmed crises only, the authors were able to demonstrate that the usage of $\mathrm{SCh}$ enhances the risk of an $\mathrm{MH}$ crisis developing when volatile anesthetics are given. [22].

\section{Conclusions}

The consistent results of IVCT and CGS show that there must be patient-associated factors that determine the severity of an $\mathrm{MH}$ reaction. Conversely clinical penetration is variable as the same patient can undergo anesthesia with triggering agents and not develop clinical signs of $\mathrm{MH}$.

In this study, a large group of patients $(n=38)$ have uncharacterized RyR1 mutations. Statistical analysis showed that these patients did develop less severe contractures and higher thresholds in the IVCT as well as lower raw score in the CGS. We conclude that this group of RyR1 mutations of unknown causality consists of both causative mutations still lacking proof of causality and non-causative RyR1 variants (polymorphisms). Also the genetic data show that the severity of $\mathrm{MH}$ varies depending on the location of the RyR1 mutation within the protein. The clinical observations of this multi-centre study indicate that the nAChR pathway might have the weakest potential in triggering an acute $\mathrm{MH}$ crisis. The data show that nearly all proven $\mathrm{MH}$ episodes were triggered by a combination of volatile anesthetics and SCh $(81 \%)$ or volatile anesthetics only $(18 \%)$. Notably the SCh only case in this study happened to a patient who showed all patient related risk factors: he was male, young (12 years old) and carried the causative RyR1 mutation p.R614C located within MH/CCD region 2 . He developed a CGS of 15 points, which represents a less severe event. An anesthetist should be aware of possible $\mathrm{MH}$ reactions to $\mathrm{SCh}$ in clinical practice and moreover should know that the combination of volatile anesthetics and $\mathrm{SCh}$ in particular is dangerous in predisposed individuals.

\section{Competing interests}

The authors declare that they have no competing interests.

\section{Authors' contributions}

WK designed the multi-centre study, supervised the IVCT in the UIm MH unit, and he also worked on the manuscript. SH helped to design the multi-centre study, collected clinical data from the UIm MH unit, did statistical calculations, drew the figures, and he also worked on the manuscript. TG collected clinical data, carried out genetic screening and supervised the IVCT experiments of the Basel MH unit; and he also worked on the manuscript. EG collected clinical data, carried out genetic screening and supervised the IVCT experiments for the Naples $\mathrm{MH}$ unit; she likewise worked on the manuscript. JH carried out $\mathrm{Ca}^{2+}$ release experiments on isolated SR in rat muscle and worked on the manuscript SJ collected clinical data, supervised the IVCT experiments of the Würzburg MH unit and worked on the manuscript. KJR carried out genetic screening at the UIm MH unit, did the polyphene analysis and worked on the manuscript. HR collected clinical data, carried out genetic screening and supervised the IVCT experiments for the Leipzig MH unit; he also worked on the manuscript. FS collected genetic data, supervised the IVCT experiments of the Würzburg MH unit and worked on the manuscript. MS collected clinical data, carried out genetic screening and supervised the IVCT experiments of the Nijmegen MH unit; he also worked on the manuscript. VS carried out genetic screening at the Padova MH unit and worked on the manuscript. VT collected clinical data and supervised the IVCT experiments of the Padova MH unit; he too worked on the manuscript. FLH collected clinical data from the UIm MH unit, supervised the multi-centre study, managed the UIm MH database and worked on the manuscript. All authors read and approved the final manuscript.

\section{Acknowledgements}

The authors would like to thank John N. French, PhD, Cork University, Ireland for help with spectrophotometry. FLH is an endowed Senior Research Professor of Neurosciences with the non-profit Hertie Foundation. KJR is a fellow of the Hertie Foundation.

\section{Author details}

${ }^{1}$ Department of Neuroanesthesiology, Ulm University, Ludwig-Heilmeyer-Str. 2, Günzburg 89312, Germany. 'Division of Neurophysiology, Ulm University, Albert-Einstein Allee 11, Ulm 89081, Germany. ${ }^{3}$ Department of Anesthesiology and Intensive Care Medicine, Hannover Medical School, Carl-Neuberg-Strasse 1, Hannover 30625, Germany. 'University of Basel, Basel, Switzerland. ${ }^{5}$ University of Naples, Naples, Italy. ${ }^{6}$ Biochemistry Department, University College Cork, Cork, Ireland. 'Department of Anesthesia and Critical Care, University of Würzburg, Würzburg, Germany. ${ }^{8}$ Rare Disease Center, University Hospital UIm, Ulm 89081, Germany. ${ }^{9}$ University of Leipzig, Helios Kliniken Leipziger Land, Leipzig, Germany. ${ }^{10}$ Department of Anesthesia, Canisius-Wilhelmina Hospital, University of Nijmegen, Nijmegen, The Netherlands. ${ }^{11}$ Molecular Medicine Section, Department of Molecular and Developmental Medicine, University of Siena, via A. Moro 2, Siena 53100, Italy. ${ }^{12}$ Department of Anesthesia, University of Padua, Padua, Italy.

Received: 28 September 2013 Accepted: 8 January 2014 Published: 16 January 2014

\section{References}

1. Rosenberg H, Davis M, James D, Pollock N, Stowell K: Malignant hyperthermia. Orphanet J Rare Dis 2007, 24:2-21.

2. Larach MG, Localio AR, Allen GC, Denborough MA, Ellis FR, Gronert GA, Kaplan RF, Muldoon SM, Nelson TE, Ording H: A clinical grading scale to predict malignant hyperthermia susceptibility. Anesthesiology 1994, 80:771-779.

3. McCarthy TV, Healy JM, Heffron JJ, Lehane M, Deufel T, Lehmann-Horn F, Farrall M, Johnson K: Localization of the malignant hyperthermia susceptibility locus to human chromosome 19q12-13.2. Nature 1990, 343:562-564.

4. MacLennan DH, Duff C, Zorzato F, Fujii J, Phillips M, Korneluk RG, Frodis W, Britt BA, Worton RG: Ryanodine receptor gene is a candidate for predisposition to malignant hyperthermia. Nature 1990, 343:559-561.

5. Monnier N, Procaccio V, Stieglitz P, Lunardi J: Malignant-hyperthermia susceptibility is associated with a mutation of the alpha 1-subunit of the human dihydropyridine-sensitive L-type voltage-dependent calciumchannel receptor in skeletal muscle. Am J Hum Genet 1997, 60:1316-1325.

6. Robinson R, Carpenter D, Shaw MA, Halsall J, Hopkins P: Mutations in RYR1 in malignant hyperthermia and central core disease. Hum Mutat 2006, 27:977-989. 
7. Kraeva N, Riazi S, Loke J, Frodis W, Crossan ML, Nolan K, Kraev A, MacLennan DH: Ryanodine receptor type 1 gene mutations found in the Canadian malignant hyperthermia population. Can J Anaesth 2011, 58:504-513.

8. Islander G, Rydenfelt K, Ranklev E, Bodelsson M: Male preponderance of patients testing positive for malignant hyperthermia susceptibility. Acta Anaesthesiol Scand 2007, 51:614-620.

9. Reed SB, Strobel GE: An in-vitro model of malignant hyperthermia: differential effects of inhalation anesthetics on caffeine-induced muscle contractures. Anesthesiology 1978, 48:254-259.

10. Britt BA, Endrenyi L, Frodis W, Scott E, Kalow W: Comparison of effects of several inhalation anaesthetics on caffeine-induced contractures of normal and malignant hyperthermic skeletal muscle. Can Anaesth Soc J 1980, 27:12-15.

11. Matsui K, Fujioka Y, Kikuchi H, Yuge O, Fujii K, Morio M, Endo M: Effects of several volatile anesthetics on the $\mathrm{Ca}(2+)$-related functions of skinned skeletal muscle fibers from the guinea pig. Hiroshima J Med Sci 1991, 40:9-13.

12. Kunst $G$, Graf BM, Schreiner R, Martin E, Fink RH: Differential effects of sevoflurane, isoflurane, and halothane on $\mathrm{Ca} 2+$ release from the sarcoplasmic reticulum of skeletal muscle. Anesthesiology 1999, 91:179-186.

13. Wedel DJ, Gammel SA, Milde JH, laizzo PA: Delayed onset of malignant hyperthermia induced by isoflurane and desflurane compared with halothane in susceptible swine. Anesthesiology 1993, 78:1138-1144.

14. Allen GC, Brubaker CL: Human malignant hyperthermia associated with desflurane anesthesia. Anesth Analg 1998, 86:1328-1331.

15. Hopkins PM: Malignant hyperthermia: pharmacology of triggering. $\mathrm{Br} \mathrm{J}$ Anaesth 2011, 107:48-56.

16. Ording H, Brancadoro V, Cozzolino S, Ellis FR, Glauber V, Gonano EF, Halsall PJ, Hartung E, Heffron JJ, Heytens L, Kozak-Ribbens G, Kress H, KrivosicHorber R, Lehmann-Horn F, Mortier W, Nivoche Y, Ranklev-Twetman E, Sigurdsson S, Snoeck M, Stieglitz P, Tegazzin V, Urwyler A, Wappler F: In vitro contracture test for diagnosis of malignant hyperthermia following the protocol of the European MH Group: results of testing patients surviving fulminant $\mathrm{MH}$ and unrelated low-risk subjects. The European Malignant Hyperthermia Group. Acta Anaesthesio/ Scand 1997, 41:955-966.

17. Eltit JM, Ding X, Pessah IN, Allen PD, Lopez JR: Nonspecific sarcolemmal cation channels are critical for the pathogenesis of malignant hyperthermia. FASEB J 2013, 27(3):991-1000.

18. Ellis FR, Keaney NP, Harriman DG, Sumner DW, Kyei-Mensah K, Tyrrell JH, Hargreaves JB, Parikh RK, Mulrooney PL: Screening for malignant hyperpyrexia. Br Med J 1972, 3:559-561

19. Halsall PJ, Ellis FR: A screening test for the malignant hyperpyrexia phenotype using suxamethonium-induced contracture of muscle treated with caffeine and its inhibition by dantrolene. Br J Anaesth 1979, 51:753-756

20. Harrison GG: Anaesthetic-induced malignant hyperpyrexia: a suggested method of treatment. Br Med J 1971, 3:454-456.

21. Metterlein T, Schuster F, Palmer E, Roewer N, Anetseder M: Succinylcholine in malignant hyperthermia: evaluation of a novel in vivo model. Muscle Nerve 2011, 44:213-216.

22. Dexter F, Epstein $\mathrm{RH}$, Wachtel RE, Rosenberg $\mathrm{H}$ : Estimate of the relative risk of succinylcholine for triggering malignant hyperthermia. Anesth Analg 2013, 116(1):118-122.

23. Herrmann-Frank A, Richter M, Sarközi S, Mohr U, Lehmann-Horn F: 4-chloro-m-cresol, a potent and specific activator of the skeletal muscle ryanodine receptor. Biochim Biophys Acta 1996, 1289:31-40.

24. Klingler W, Lehmann-Horn F, Jurkat-Rott K: Complications of anaesthesia in neuromuscular disorders. Neuromuscul Disord 2005, 15(3):195-206.

25. Klingler W, Heffron JJ, Jurkat-Rott K, O'sullivan G, Alt A, Schlesinger F, Bufler J, Lehmann-Horn F: 3,4-Methylenedioxymethamphetamine (ecstasy) activates skeletal muscle nicotinic acetylcholine receptors. J Pharmacol Exp Ther 2005, 314:1267-1273.

26. Zullo A, Klingler W, De Sarno C, Ferrara M, Fortunato G, Perrotta G, Gravino E, Di Noto R, Lehmann-Horn F, Melzer W, Salvatore F, Carsana A: Functional characterization of ryanodine receptor (RYR1) sequence variants using a metabolic assay in immortalized B-lymphocytes. Hum Mutat 2009, 30(4):E575-E590.

27. O'Sullivan GH, McIntosh JM, Heffron JJ: Abnormal uptake and release of Ca2+ ions from human malignant hyperthermia-susceptible sarcoplasmic reticulum. Biochem Pharmacol 2001, 61:1479-1485.

28. Tammaro A, Bracco A, Cozzolino S, Esposito M, Di Martino A, Savoia G, Zeuli $L$, Piluso G, Aurino S, Nigro V: Scanning for mutations of the ryanodine receptor (RYR1) gene by denaturing HPLC: detection of three novel malignant hyperthermia alleles. Clin Chem 2003, 49:761-768.

29. Quane KA, Keating KE, Manning BM, Healy JM, Monsieurs K, Heffron J, Lehane M, Heytens L, Krivosic-Horber R, Adnet P: Detection of a novel common mutation in the ryanodine receptor gene in malignant hyperthermia: implications for diagnosis and heterogeneity studies. Hum Mol Genet 1994, 3:471-476.

30. Galli L, Orrico A, Lorenzini S, Censini S, Falciani M, Covacci A, Tegazzin V, Sorrentino V: Frequency and localization of mutations in the 106 exons of the RYR1 gene in 50 individuals with malignant hyperthermia. Hum Mutat 2006, 27:830

31. Davis $M$, Brown $R$, Dickson $A$, Horton $H$, James $D$, Laing $N$, Marston $R$, Norgate M, Perlman D, Pollock N, Stowell K: Malignant hyperthermia associated with exercise-induced rhabdomyolysis or congenital abnormalities and a novel RYR1 mutation in New Zealand and Australian pedigrees. Br J Anaesth 2002, 88:508-515.

32. Rueffert $H$, Olthoff $D$, Deutrich $C$, Meinecke CD, Froster UG: Mutation screening in the ryanodine receptor 1 gene (RYR1) in patients susceptible to malignant hyperthermia who show definite IVCT results: identification of three novel mutations. Acta Anaesthesiol Scand 2002 46:692-698.

33. Gillard EF, Otsu K, Fujii J, Duff C, de Leon S, Khanna VK, Britt BA, Worton RG, MacLennan DH: Polymorphisms and deduced amino acid substitutions in the coding sequence of the ryanodine receptor (RYR1) gene in individuals with malignant hyperthermia. Genomics 1992, 13:1247-1254.

34. Quane KA, Ording H, Keating KE, Manning BM, Heine R, Bendixen D, Berg K, Krivosic-Horber R, Lehmann-Horn F, Fagerlund T, McCarthy TV: Detection of a novel mutation at amino acid position 614 in the ryanodine receptor in malignant hyperthermia. Br J Anaesth 1997, 79:332-337.

35. Rueffert $H$, Kraus H, Olthoff D, Deutrich C, Froster UG: Identification of a novel mutation in the ryanodine receptor gene (RYR1) in patients with malignant hyperthermia. Hum Mutat 2001, 17:238.

36. Manning BM, Quane KA, Ording H, Urwyler A, Tegazzin V, Lehane $M$ O'Halloran J, Hartung E, Giblin LM, Lynch PJ, Vaughan P, Censier K, Bendixen D, Comi G, Heytens L, Monsieurs K, Fagerlund T, Wolz W, Heffron JJ, Muller CR, McCarthy TV: Identification of novel mutations in the ryanodinereceptor gene (RYR1) in malignant hyperthermia: genotype-phenotype correlation. Am J Hum Genet 1998, 62:599-609.

37. Sambuughin N, Holley H, Muldoon S, Brandom BW, de Bantel AM, Tobin JR, Nelson TE, Goldfarb LG: Screening of the entire ryanodine receptor type 1 coding region for sequence variants associated with malignant hyperthermia susceptibility in the north american population. Anesthesiology 2005, 102:515-521.

38. Levano S, Vukcevic M, Singer M, Matter A, Treves S, Urwyler A, Girard T: Increasing the number of diagnostic mutations in malignant hyperthermia. Hum Mutat 2009, 30:590-598.

39. Marchant CL, Ellis FR, Halsall PJ, Hopkins PM, Robinson RL: Mutation analysis of two patients with hypokalemic periodic paralysis and suspected malignant hyperthermia. Muscle Nerve 2004, 30:114-117.

40. Sambuughin N, Nelson TE, Jankovic J, Xin C, Meissner G, Mullakandov M, J J, Rosenberg H, Sivakumar K, Goldfarb LG: Identification and functional characterization of a novel ryanodine receptor mutation causing malignant hyperthermia in North American and South American families. Neuromuscul Disord 2001, 11:530-537.

41. Rüffert $H$, Olthoff $D$, Deutrich C, Froster UG: [Current aspects of the diagnosis of malignant hyperthermia]. Anaesthesist 2002, 51:904-913.

42. Sambuughin N, Sei Y, Gallagher KL, Wyre HW, Madsen D, Nelson TE, Fletcher JE, Rosenberg H, Muldoon SM: North American malignant hyperthermia population: screening of the ryanodine receptor gene and identification of novel mutations. Anesthesiology 2001, 95:594-599.

43. Chamley D, Pollock NA, Stowell KM, Brown RL: Malignant hyperthermia in infancy and identification of novel RYR1 mutation. Br J Anaesth 2000, 84:500-504

44. Brandt A, Schleithoff L, Jurkat-Rott K, Klingler W, Baur C, Lehmann-Horn F: Screening of the ryanodine receptor gene in 105 malignant hyperthermia families: novel mutations and concordance with the in vitro contracture test. Hum Mol Genet 1999, 8:2055-2062.

45. Barone V, Massa O, Intravaia E, Bracco A, Di Martino A, Tegazzin V, Cozzolino S, Sorrentino V: Mutation screening of the RYR1 gene and identification of two novel mutations in Italian malignant hyperthermia families. J Med Genet 1999, 36:115-118. 
46. Manning BM, Quane KA, Lynch PJ, Urwyler A, Tegazzin V, Krivosic-Horber R, Censier K, Comi G, Adnet P, Wolz W, Lunardi J, Muller CR, McCarthy TV: Novel mutations at a $\mathrm{CpG}$ dinucleotide in the ryanodine receptor in malignant hyperthermia. Hum Mutat 1998, 11:45-50.

47. Dekomien G, Gencik M, Gencikova A, Klenk Y, Epplen JT: Gene symbol: RYR1. Disease: malignant hyperthermia. Hum Genet 2005, 118:543.

48. Jungbluth $H$, Müller $C R$, Halliger-Keller B, Brockington M, Brown SC, Feng L, Chattopadhyay A, Mercuri E, Manzur AY, Ferreiro A, Laing NG, Davis MR, Roper HP, Dubowitz V, Bydder G, Sewry CA, Muntoni F: Autosomal recessive inheritance of RYR1 mutations in a congenital myopathy with cores. Neurology 2002, 59:284-287.

49. Monnier N, Kozak-Ribbens G, Krivosic-Horber R, Nivoche Y, Qi D, Kraev N, Loke $J$, Sharma P, Tegazzin V, Figarella-Branger D, Roméro N, Mezin P, Bendahan D, Payen JF, Depret T, Maclennan DH, Lunardi J: Correlations between genotype and pharmacological, histological, functional, and clinical phenotypes in malignant hyperthermia susceptibility. Hum Mutat 2005, 26:413-425.

50. Groom L, Muldoon SM, Tang ZZ, Brandom BW, Bayarsaikhan M, Bina S, Lee HS, Qiu X, Sambuughin N, Dirksen RT: Identical de novo mutation in the type 1 ryanodine receptor gene associated with fatal, stress-induced malignant hyperthermia in two unrelated families. Anesthesiology 2011, 115(5):938-945.

51. Vukcevic M, Broman M, Islander G, Bodelsson M, Ranklev-Twetman E, Müller $C R$, Treves S: Functional properties of RYR1 mutations identified in Swedish patients with malignant hyperthermia and central core disease. Anesth Analg 2010, 111:185-190.

52. Larach MG, Gronert GA, Allen GC, Brandom BW, Lehman EB: Clinical presentation, treatment, and complications of malignant hyperthermia in North America from 1987 to 2006. Anesth Analg 2010, 110(2):498-507.

53. Carpenter D, Robinson RL, Quinnell RJ, Ringrose C, Hogg M, Casson F, Booms P, Iles DE, Halsall PJ, Steele DS, Shaw MA, Hopkins PM: Genetic variation in RYR1 and malignant hyperthermia phenotypes. $\mathrm{Br} J$ Anaesth 2009, 103:538-548.

54. Fucile S, Sucapane A, Grassi F, Eusebi F, Engel AG: The human adult subtype ACh receptor channel has high $\mathrm{Ca} 2+$ permeability and predisposes to endplate Ca2+ overloading. J Physiol 2006, 15;573(Pt 1):35-43.

55. Protasi F: Structural interaction between RYRs and DHPRs in calcium release units of cardiac and skeletal muscle cells. Front Biosci 2002, 7:d650-d658.

56. Pollock AN, Langton EE, Couchman K, Stowell KM, Waddington M: Suspected malignant hyperthermia reactions in New Zealand. Anaesth Intensive Care 2002, 30(4):453-461.

doi:10.1186/1750-1172-9-8

Cite this article as: Klingler et al:: Functional and genetic

characterization of clinical malignant hyperthermia crises: a multi-centre study. Orphanet Journal of Rare Diseases 2014 9:8.

\section{Submit your next manuscript to BioMed Central and take full advantage of:}

- Convenient online submission

- Thorough peer review

- No space constraints or color figure charges

- Immediate publication on acceptance

- Inclusion in PubMed, CAS, Scopus and Google Scholar

- Research which is freely available for redistribution

Submit your manuscript at www.biomedcentral.com/submit
Ciomed Central 